DOI: $10.22616 /$ j.balticsurveying.2019.005

\title{
STUDY OF THE NATURAL HERITAGE CONDITION OF THE KURSIU NERIJA NATIONAL PARK USING LIDAR TECHNOLOGY (CASE STUDY OF AGILA DUNE)
}

\author{
Deimantė Pankauskyte ${ }^{1}$, Jolanta Valčiukiene ${ }^{1}$, Indrius Kuklys ${ }^{2}$, Lina Kukliene ${ }^{2}$ \\ ${ }^{1}$ Vytautas Magnus University Agriculture Academy \\ ${ }^{2}$ Klaipeda State University
}

\begin{abstract}
Summary
Analysis of the condition of the Agila dune is presented in this Article. The analysis is based on data collected during accurate geodetic measurements using LIDAR technology. The current state of the Agila dune was compared to the data of the previous year's LIDAR points in order to ensure the reliability and value of the research.

In the course of the study, eleven cross sections were compared by height differences with previous year's measurements. The condition of the Agila dune was found to be the worst in three cross sections. First cross section's erosion measured at 13,98 meters, erosion in the fifth cross section -9.90 meters, and erosion in the eighth cross section - 11.34 meters. The main reasons for the deterioration of the natural values of the Kursiu Nerija National Park are climate, wind, high visitor flows and the persistent failure to carry out comprehensive research. Therefore, in order to preserve these unique natural values, it is important to collect large-scale and high-precision data on the status of these values, to systematize, analyze and take appropriate protective measures.
\end{abstract}

Keywords: Agila dune, values of nature, LIDAR, erosion, accumulation.

\section{Introduction}

Protected areas are land and / or water areas with clear boundaries, which have a recognized scientific, ecological, cultural and other value that is subject to a specific protection and use regime by law. The Law on the Protected Areas establishes and regulates the public relations related to protected areas, the system of protected areas, the legal bases for the establishment, protection, management and control of protected areas. Protected areas in Lithuania are divided into reserves, heritage objects and state parks (Lietuvos ..., 2001). There are 5 national parks in the territory of the Republic of Lithuania, one of the most impressive national parks is the Kursiu Nerija. It was included in the UNESCO World Heritage List in December 2000.

The Kursiu Nerija National Park is distinguished by its unique landscape. This is definitely the most valuable protected area in Lithuania. In protected areas such as state parks one of the most important goals should be tourism development (Kulczyk-Dynowska, 2015). The Kursiu Nerija has a great recreational potential, but it is also vulnerable to anthropogenic impact. One of the most visited sites in the Kursiu Nerija is the Agila Dune in Nagliai Nature Reserve. This natural value is really worrying, and the condition of this monument is the worst in the Kursiu Nerija, which is included in the cadastre of all nature monuments. The dunes are sensitive to tourist visits, and previous studies have shown that every person walking around the dune moves a few tons of sand and speeds up the erosion of the dunes.

There are over 209,000 protected areas around the world, of which more than 20,000 are declared World Heritage Sites. The main task of protected areas is to preserve natural and cultural values (Lee, 2016).

Monitoring is required to systematically assess the protection, preservation and representativeness of natural values in protected areas (Regos et al., 2017). The national and international status of the park proves the value and uniqueness of this area and its importance for the Lithuanian landscape. However, visual observations do not make it possible to accurately determine the dune condition and degree of deterioration. Therefore, it would be important to collect data on the state of natural values with accurate geodetic instruments, to systematize and analyze them. It would be useful to integrate the data received into a common spatial data set that would allow analysis and take preventive actions. 
The continuous development of measurement technologies also increases the variety of data collection methods. One of the newest and most advanced ways to do this is remote sensing method used for primary data collection. Remote sensing is the science of obtaining information about physical, biological and chemical properties of objects without physical contact. Remote sensing is the main source of spatial information on the Earth's surface (Guo et al., 2017; Schowengerdt, 2007).

Remote research methods are one of the most effective ways to study and monitor the landscape. Laser Scanning (LIDAR) is a way to get data for landscape assessment. For many years, these data have been used in science of nature, technology and geography. Using the LIDAR technology, a 3D point cloud is obtained: X, Y and Z coordinates (Dudzinska et al., 2017; Melin et al., 2017; Traviglia et al., 2017).

LIDAR is a method for obtaining more accurate data than information from orthophotographic maps. Laser scanning is believed to be one of the most accurate measurement methods. This allows to record huge amounts of spatial data at high speed and accuracy (Michalowska, 2015).

Research on the condition of Agila dune was carried out by applying the LIDAR method, which is the most advanced technology that allows to make competent decisions. The results obtained are particularly valuable as they are accurate and complete.

The aim of the study - to analyze the condition of the natural values of the Kursiu Nerija National Park - Agila Dune

Object of research - Natural value of the Kursiu Nerija National Park - Agila Dune.

The following tasks are raised to achieve the goal:

1. To study changes in the surface of Agila Dune by comparing LIDAR data of years 2010 and 2019.

2. To create a 3D model of the Agila Dune surface.

\section{Methodology}

At the first stage of the study, natural measurements method was used. During this stage the change of Agila dune was studied. In order to accomplish the tasks, SEZP_0.5LT was used - digital spatial laser scanning of the territory of the Republic of Lithuania for the year 2010, ordered from the website www.geoportal.lt. Also in 2019 In March, new measurements were made on unmanned aircraft using LIDAR technology.

Before commencing measurements, a flight path had to be created (Fig. 1).
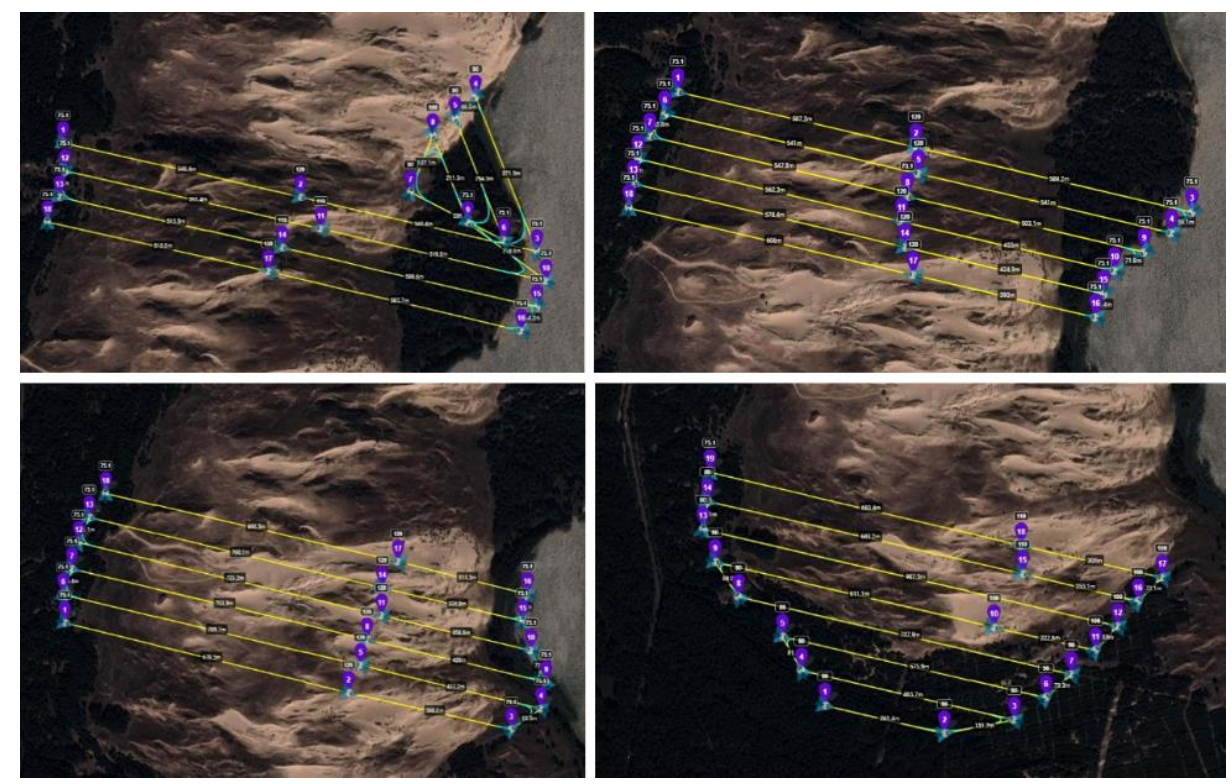

Fig. 1. Flight routes

As the analyzed object covers an area of over 100 ha, four routes were created. The distance between the flight paths is $75 \mathrm{~m}$ to cover the entire surface. During the measurements, the flight height was between $75 \mathrm{~m}$ and $120 \mathrm{~m}$, depending on the difference in dune height. Measurements of the Agila Dune were started after creating flight routes and acquiring permission to visit the Nagliai Nature 
Reserve from the Directorate of the Kursiu Nerija National Park. Measurements were performed using the Ibeo first-class LIDAR laser. The density of its measuring points depends on two indicators speed and altitude (Fig. 2).

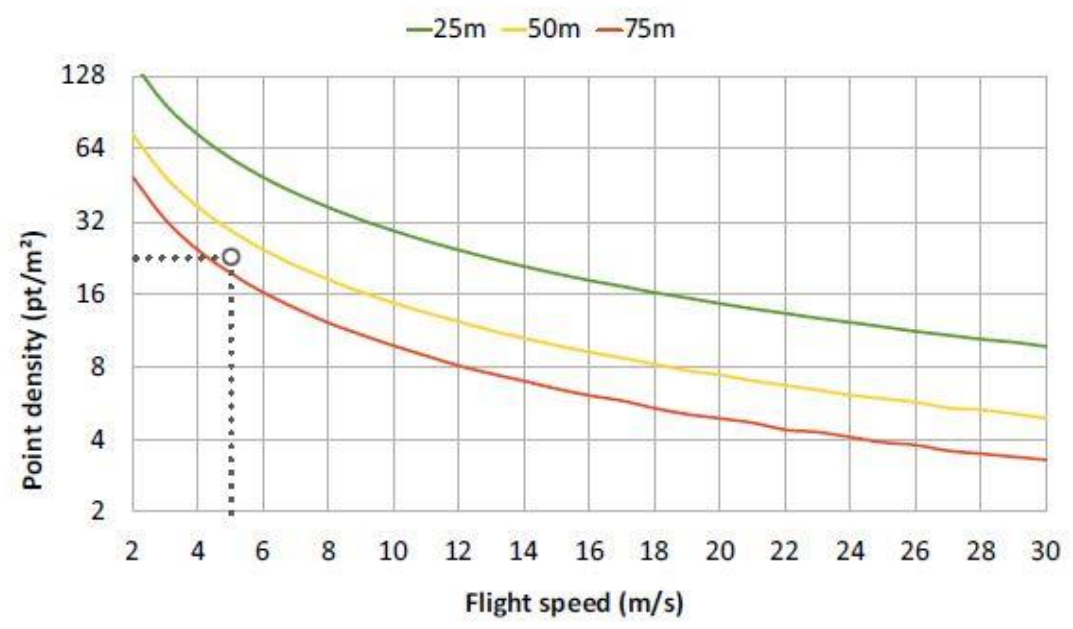

Fig. 2. Used laser flight parameters (YellowScan Mapper II..., 2019)

When flying high, the field of laser vision increases, therefore the density of points decreases. During the measurements, the flight speed was $9 \mathrm{~m} / \mathrm{s}$, height - from $75 \mathrm{~m}$. up to $120 \mathrm{~m}$. Average density of points resulted in 6 to 8 points per square meter.

After field measurements and processing of LIDAR data, further analysis was performed using GIS technologies, i.e. ArcGIS application ArcMap, programs ArcCatalog, ArcScene, and Excel. Total area of the Agila dune selected for the study is 107.11 ha. The dune condition study was carried out using height comparison method in cross sections divided by a distance of $100 \mathrm{~m}$ among them. A 3D surface model was created in ArcScene program, using specially designed algorithms that take dots and convert them to a digital 3D surface. The study was carried out to collect data on the condition of the dune, which would identify sites of sand erosion and accumulation.

In the second stage, an electronically performed questionnaire analysis method was used. 172 respondents from all over Lithuania participated in the survey. Duration of the survey - since 2019 March 5 until April 2. During the survey, 10 questions were presented which helped to reveal the public's attitude towards the natural values of the Kursiu Nerija National Park.

\section{Discussion and results}

The study was performed by creating cross sections (11 in total) and comparing them by height (Fig. $3)$.

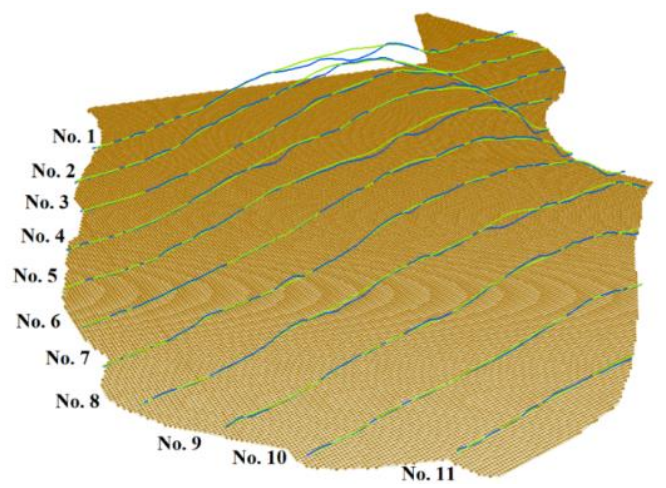

Fig. 3. 3D model of cross sections 
The figure below illustrates the 3D model of all cross sections, on the basis of which Agila dune analysis was performed.

Below are the cross sections showing the most significant dune change.

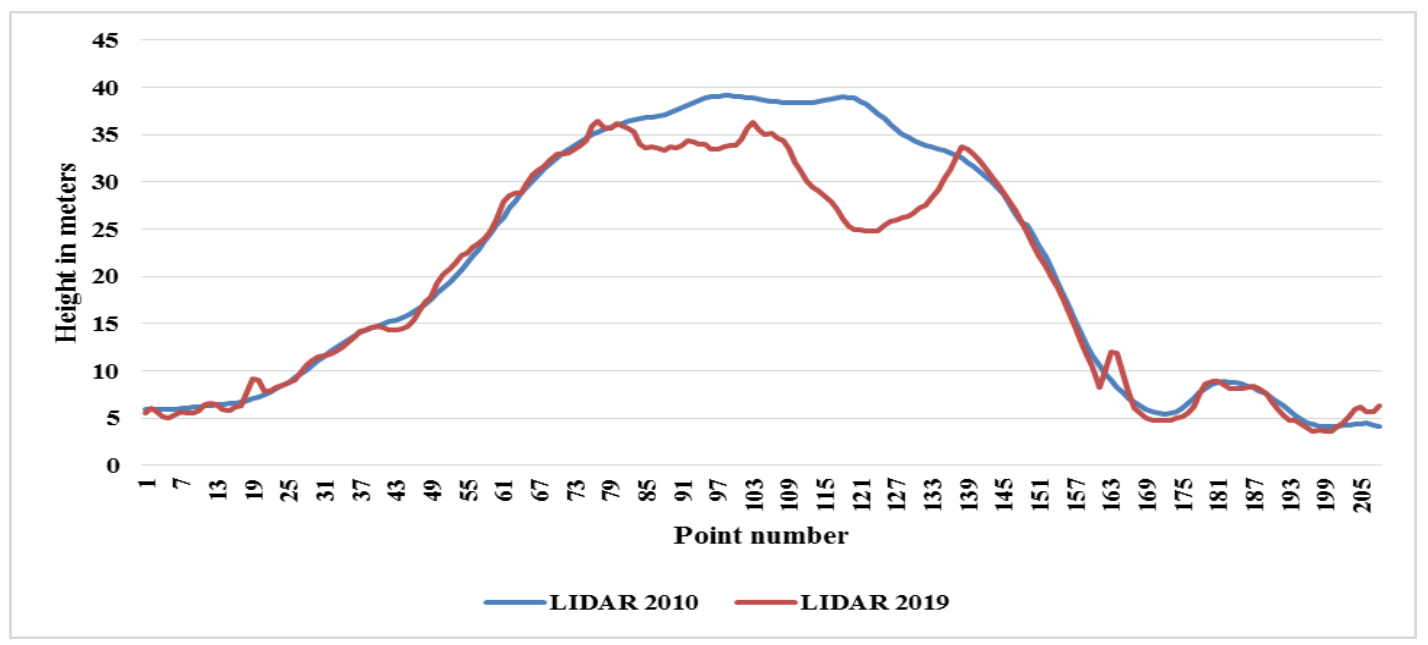

Fig. 4. Cross section No. 1

After creating cross section 1 (Fig. 4), the change of dune relief was calculated using the height difference method. With the help of Excel, the change in heights was calculated - the highest and lowest values were identified (erosion and accumulation). The highest sand erosion is recorded in the cross section at point 120, the dune in this place has dropped even $13.98 \mathrm{~m}$. At point 164 , sand accumulation was recorded at $3.59 \mathrm{~m}$. Such changes of the surface of the dune are captured in this cross section because the dune descends and spreads sideways, and the first cross section is created on the very side of the dune.

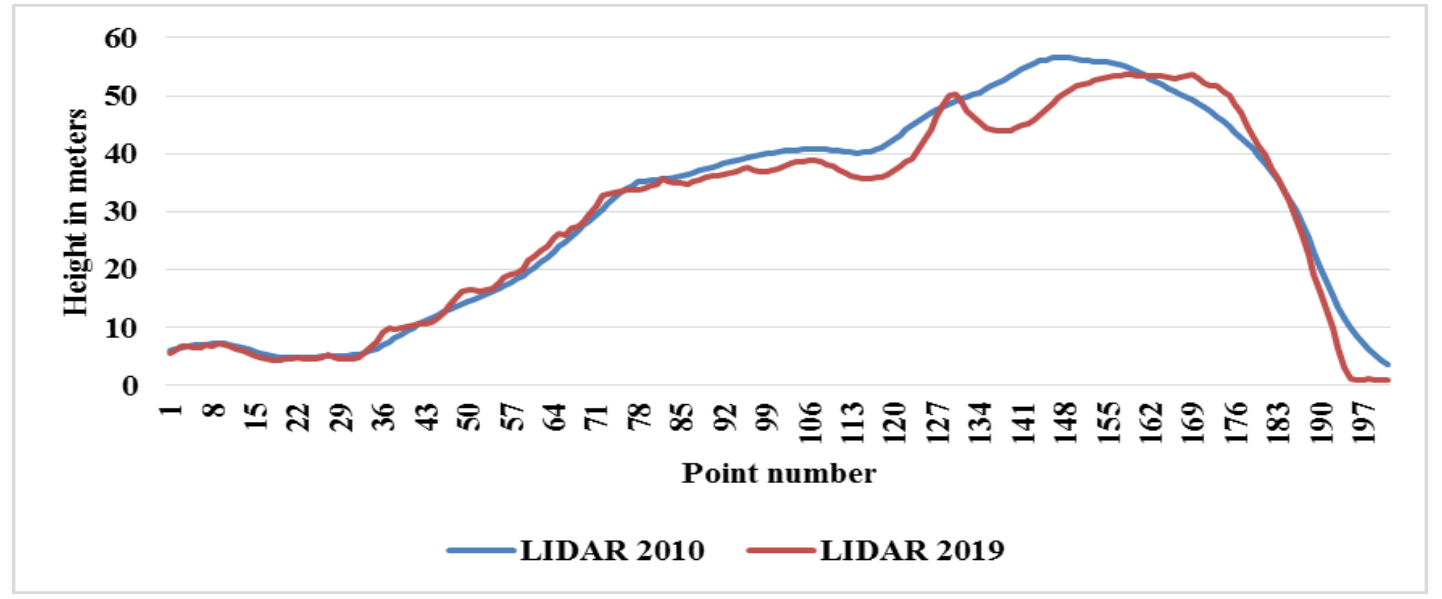

Fig. 5. Cross section No. 5

In cross section 5 (Fig. 5), two segments are visible, where significant sand erosion is observed. The highest sand erosion is recorded in the cross section at point 142. The heigth of dune in this place decreased by $9.90 \mathrm{~m}$. The sand accumulation at point 175 point reaches $5.22 \mathrm{~m}$. According to the chart, we can say that the dune in this section slides into the lagoon. This cross section is created at the trail of the Nagliai Nature Reserve, so we can assume that in this place such a change of terrain arose due to excessive flows of visitors and walking in forbidden areas, i.e. outside the trail. 


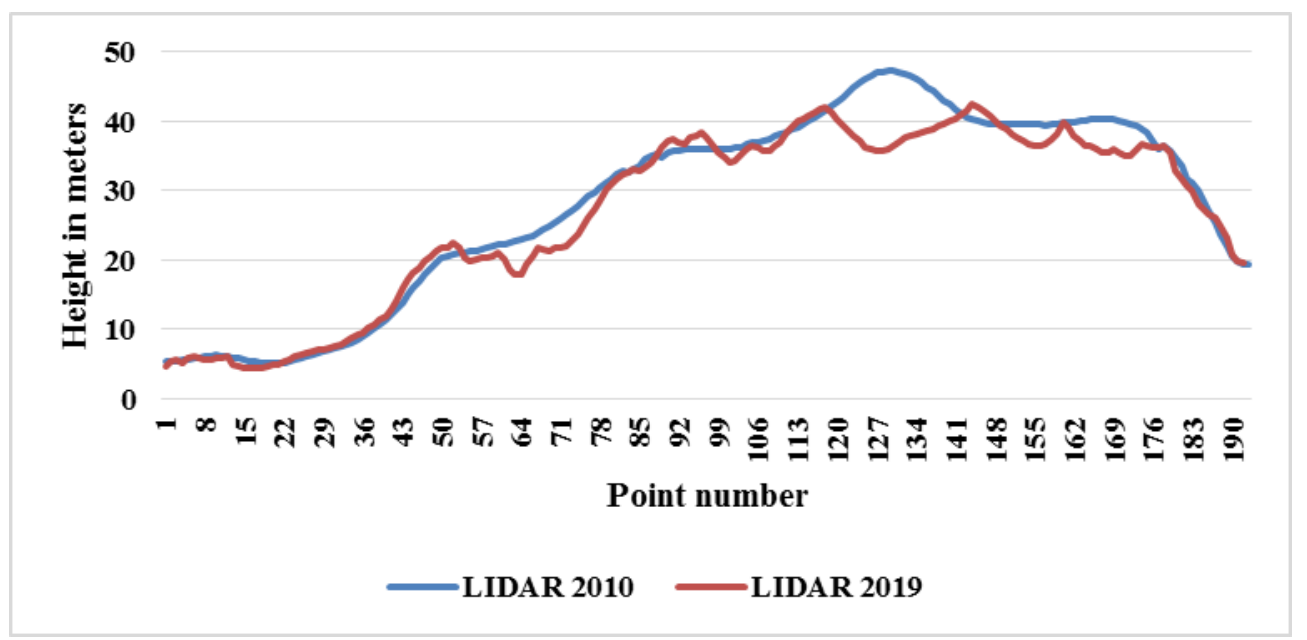

Fig. 6. Cross section No. 8

Cross section 8 (Fig. 6) shows a noticeable change in dune's terrain. The highest sand erosion is recorded at point 128 - the height of dune in this place decreased by $11.34 \mathrm{~m}$. At point 96 , the sand accumulates to $2.35 \mathrm{~m}$. This cross section was created on the right side from the Nagliai trail. Dune sand is drooping and expanding sideways.

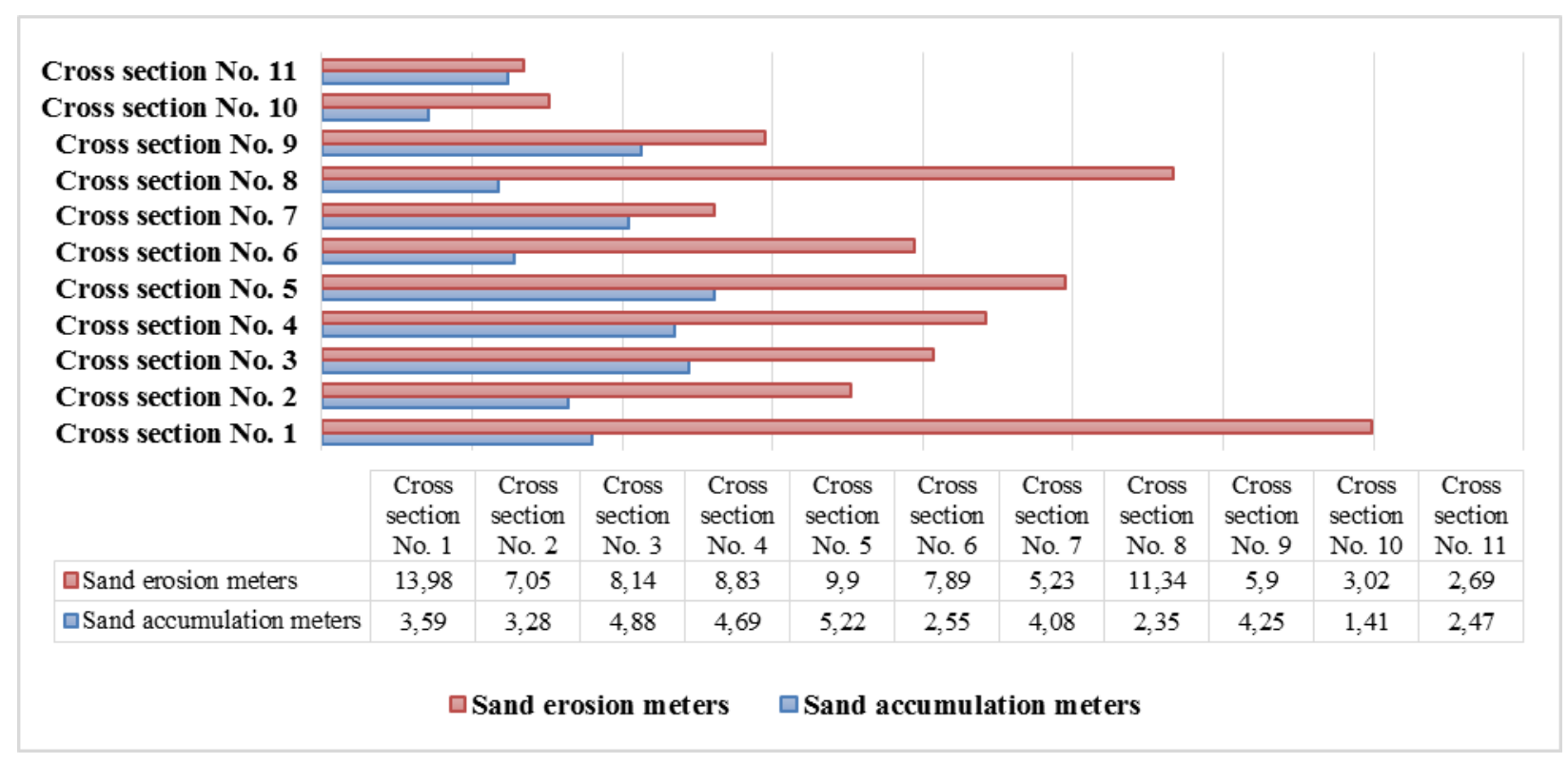

Fig. 7. Sand height changes in cross sections

The diagram (Fig. 7) provides information on all cross sections. Based on the results obtained, we can state that the most aggressive change is seen in the section no. 1, where the height of the dune has dropped by even $13.98 \mathrm{~m}$. Sand accumulation in this section reaches up to $3.59 \mathrm{~m}$. Also significant sand erosion is recorded in section no. $8-11.34 \mathrm{~m}$. and accumulation $-2.35 \mathrm{~m}$. The highest dune accumulation of $5.2 \mathrm{~m}$. is observed in section no. 5, where dune erosion is recorded up to $9.9 \mathrm{~m}$.

A visual model developed by ArcScene software was used for visual comparison of the dune surface (Fig. 8). Visual results of dune changes were obtained by overlaying 2010 and 2019 LIDAR laser scanning data. In the program, altitude data was classified and displayed on the selected color scale. LIDAR 2010 in the case of the dune ascending the color red intensifies, in the case of LIDAR 2019 data - the color purple intensifies once the heigth is increasing. 

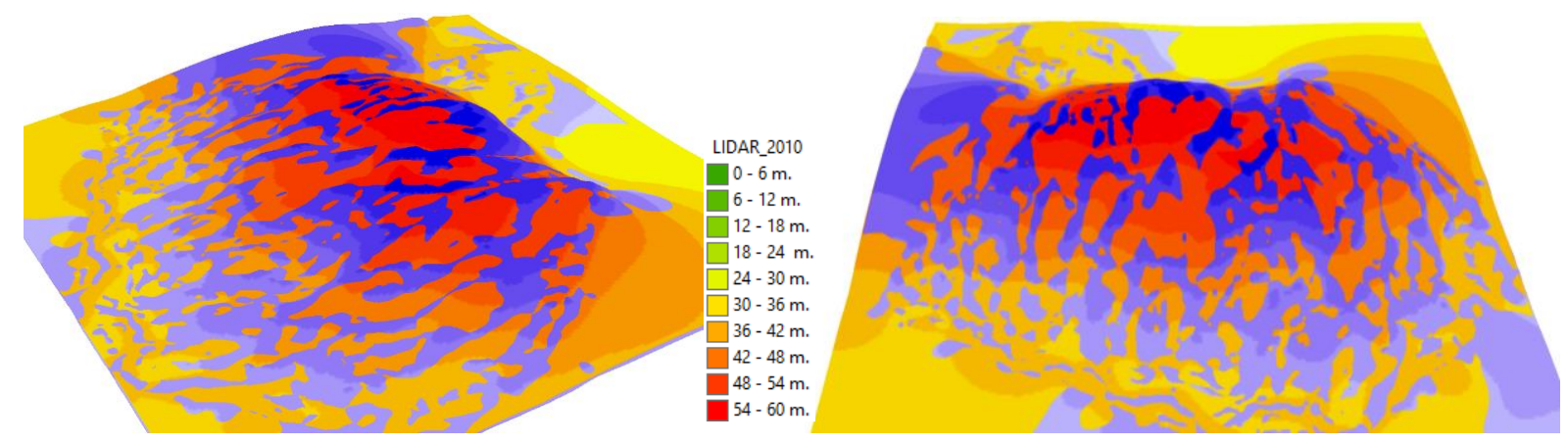

Fig. 8. 3D model of Agila dune surface

With the help of the created 3D model we can see the most problematic places of Agila dune, the biggest loss of sand (erosion) in the picture is marked in red.

In order to substantiate the full value of the research, a questionnaire was conducted (Fig. 9), in which 172 respondents participated. The survey showed that this unique landscape of the Kursiu Nerija, created by natural and human forces, is proven to be an area of exceptional value not only by specialists and scientists, but also by opinion of respondents. According to the survey data, $72.1 \%$ of respondents appreciate Kursiu Nerija as the most popular resort in Lithuania, and according to $78.5 \%$ of the respondents, this is determined by the uniqueness of the landscape.
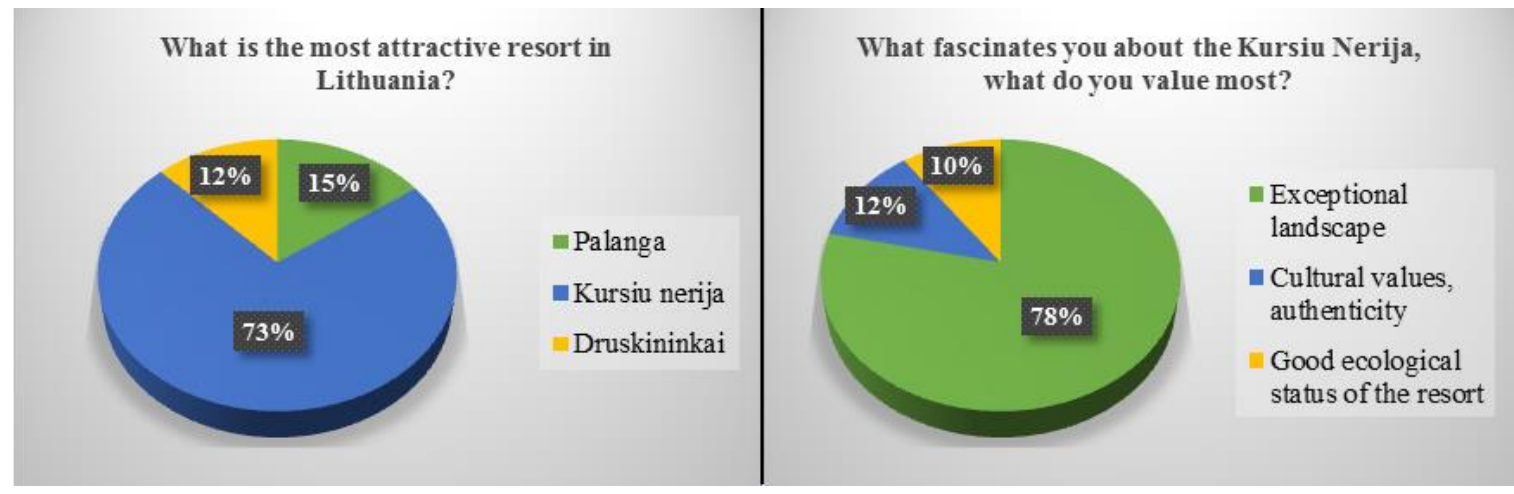

Fig. 9. Partial results of the survey

During the survey, respondents were asked whether they often see people walking in dunes where it is forbidden to do so. $44.2 \%$ of those surveyed said that they see visitors walking in the restricted areas every time they are visiting the resort, and even $24 \%$ of the respondents said they liked to go out to the forbidden zones themselves. In the respondents' opinion, the greatest impact on the deterioration of the environment is the lack of awareness of the people, and the most effective way to preserve natural values from extinction is more intensive control and funds of the European Union, which would ensure effective protection and preservation of natural values.

To summarize, we can state that in 9 years the dune has changed its shape, the structure of sand has changed, dunes are moving to the Kursiu Lagoon.

\section{Conclusions and recommendations}

1. The study showed that the most aggressive change in Agila Dune was noticeable in cross section no. 1 - dune erosion reaches $13.98 \mathrm{~m}$. and sand accumulation in this section is $3.59 \mathrm{~m}$. Also significant sand erosion is recorded in section no. $8-11.34 \mathrm{~m}$. and accumulation $-2.35 \mathrm{~m}$. The highest dune accumulation of $5.2 \mathrm{~m}$. is observed in section no. 5, where dune erosion is recorded up to $9.9 \mathrm{~m}$. In 9 years the dune has changed its shape, the structure of the sand has changed, the dunes are moving to the Kursiu Lagoon, the winds are causing the greatest damage to the dune, but irresponsible human behavior also contributes to it. 
2. With the help of the created 3D model we can see the most problematic places of Agila Dune, the identification and monitoring of which can help to take appropriate protection measures in these zones in order to preserve this unique natural value of the Kursiu Nerija National Park.

\section{References}

1. Dudzinska A., Szpakowska B., Walerzak M. (2017). The Use of Lidar Data to ASSESS Elements of Rural Landscape Architecture. Science, Nature, Technologies / Nauka, Przyroda, Technologie. Vol. 54, Issue 2, pp. 239-252.

2. Guo, M., Li, J., Sheng, Ch., Xu, J., Wu, L. (2017). A Review of Wetland Remote Sensing. Sensors. Vol. $17,777 \mathrm{p}$.

3. YellowScan Mapper II. Viewed 19 March, 2019, (https://www.yellowscan-lidar.com/products/yellowscanmapper2).

4. Kulczyk-Dynowska, A. (2015). The Spatial and Financial Aspects of a Protected Area as Exemplified By the Roztocze National Park. Research Papers of the Wroclaw University of Economics / Prace Naukowe Uniwersytetu Ekonomicznego we Wroclawiu. Issue 394, p45-53. 9p.

5. Lee, E. (2016) Protected Areas, Country and Value: The Nature-Culture Tyranny of the IUCN's Protected Area Guidelines for Indigenous Australians. Antipode. Vol. 48 Issue 2, p355-374. 20p.

6. Lietuvos Respublikos saugomų teritorijų ịstatymas. Iš: Valstybės žinios, 2001, Nr. 58-1703.

7. Michalowska, K. (2015). Modelowanie i wizualizacja danych 3D na podstawie pomiarow fotogrametrycznych i skaningu laserowego. Rzeszow. 61p.

8. Melin, M., C.Shapiro, A., Glover-Kapfer, P. (2017). Remote Sensing: LIDAR. United Kingdom: WWF Conservation Technology Series 1(3), $10 \mathrm{p}$.

9. Regos, A., Tapia, L., Gil-Carrera, A., Dominguez, J. (2017). Monitoring Protected Areas from Space: A multi-temporal assessment using raptors as biodiversity surrogates. Plos One. Vol. 12 (7), pp. e0181769.

10. Schowengerdt, R. A. (2007). Remote sensing: models and methods for image processing. Academic Press.

11. Traviglia, A., Torsello, A. (2017). Landscape Pattern Detection in Archaeological Remote Sensing. Geosciences (2076-3263). Vol. 7 Issue 4, p128. 16p.

Information about authors:

Deimantė Pankauskytė student of Master degree in Faculty of Water and Land Management, Vytautas Magnus University Agriculture Academy. Address: Universiteto 10, LT-53361, Akademija, Kaunas distr., Lithuania, Phone No.+37065883659, E-mail: deimantepan@gmail.com.

Jolanta Valčiukienė director and associate professor at the Institut of Land Management and Geomatics in Faculty of Water and Land Management, Vytautas Magnus University Agriculture Academy. Address: Universiteto 10, LT-53361, Akademija, Kaunas distr., Lithuania, Phone No. +37037752372, E-mail: jolanta.valciukiene@ vdu.lt. Fields of interest: spatial planning, balanced urban development, rational land use, land law.

Indrius Kuklys lecturer in Klaipeda State University of Applied Sciences, Faculty of Technologies, Department of Environment and Construction Engineering. Address: Bijūnų str. 10, LT- 91223 Klaipėda, Lithuania, Phone No. +37069973057, E-mail: i.kuklys@kvk.lt. Fields of interest: geoinformation systems, accuracy of measurements, remote sensing technologies (LIDAR).

Lina Kuklienė lecturer in Klaipeda State University of Applied Sciences, Faculty of Technologies, Department of Environment and Construction Engineering. Address: Bijūnų str. 10, LT- 91223 Klaipėda, Lithuania, Phone No. +37069973076, E-mail: 1.kukliene@ @vk.lt. Fields of interest: geoinformation systems, digital mapping. 